\title{
PERAN ORANG TUA DALAM PEMENUHAN HAK PENDIDIKAN ANAK PADA MASA BELAJAR DARI RUMAH
}

\author{
Oksiana Jatiningsih $^{1 *}$, Siti Maizul Habibah ${ }^{1}$, Rahmanu Wijaya ${ }^{1}$, Maya Mustika Kartika Sari ${ }^{1}$ \\ ${ }^{1}$ Universitas Negeri Surabaya, Indonesia \\ *e-mail: oksianajatiningsih@unesa.ac.id
}

\begin{abstract}
Abstrak
Pandemi COVID-19 berdampak pada keharusan dilakukannya pembelajaran dari rumah. Hal ini berdampak pada perubahan cara anak dalam belajar dan peran orang tua untuk melakukan pendampingan dalam belajar. Karena itu, penelitian ini bertujuan untuk mendeskripsikan bagaimanakah peran orang tua dalam melakukan pendampingan belajar terhadap anaknya. Penelitian ini dirancang untuk menggunakan pendekatan kualitatif. Penelitian ini dilaksanakan di Surabaya, pada keluarga yang memiliki anak dengan usia sekolah dasar. Subjek penelitian dalam penelitian ini adalah sembilan orang diambil dengan menggunakan teknik purposive, berdasarkan kriteria memiliki anak yang sedang bersekolah di jenjang sekolah dasar. Pengambilan data dilakukan dengan menggunakan teknik wawancara. Selanjutnya, data yang diperoleh dalam penelitian ini dianalisis secara naratif kualitatif dengan menggunakan teknik interaktif dari Miles dan Huberman. Adapun peran orang tua dalam pemenuhan hak anak untuk memperoleh pendidikan adalah mendampingi anak dalam belajar, menyediakan fasilitas belajar anak, dan memotivasi anak. Sedangkan pembagian peran orang tua dalam pendampingan belajar anak, dapat dijelaskan bahwa sebagian besar peran itu dijalankan oleh ibu. Sesuai dengan konstruksi gender patriarkhi, ayah berperan mencari nafkah, sehingga kegiatan pendampingan anak tanpa disadari telah disepakati dikerjakan oleh ibu. Temuan ini menunjukkan kuatnya nilai gender patriarkhi berlaku di masyarakat.
\end{abstract}

Kata Kunci: Belajar Dari Rumah; Peran Orang Tua; Anak; Hak Pendidikan

\begin{abstract}
The COVID-19 pandemic has an impact on the necessity of learning from home. The impacts were changing the way children learn and the role of parents to assist in learning. Therefore, this study aims to describe how parents' role in providing learning assistance for their children. This research is designed to use a qualitative approach. This research was conducted in Surabaya, in families who have children of elementary school age. The research subjects in this study were nine people who were taken using a purposive technique, based on the criteria of having children who are currently attending elementary school level. Data were collected using interview techniques. Furthermore, the data obtained in this study were analyzed in a qualitative narrative using interactive techniques from Miles and Huberman. Parents' role in fulfilling children's rights to education is assisting children in learning, providing learning facilities for children, and motivating children. While the division of parents' roles in child learning assistance, it can be explained that most of the roles are carried out by mothers. Following the gender patriarchal construction, the father has the role of earning a living, so that the child assistance activities have been unwittingly agreed upon by the mother. This finding shows the strength of the patriarchal gender values prevailing in society.
\end{abstract}

Keywords: Learning from Home; Parents's Role; Child; Education Right

This is an open access article under the CC BY-SA license.

Copyright (C 2021 by Author. Published by Universitas Pendidikan Ganesha.

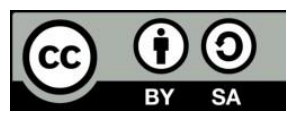


Oksiana Jatiningsih, Siti Maizul Habibah, Rahmanu Wijaya, Maya Mustika Kartika Sari | Peran Orang Tua Dalam Pemenuhan Hak Pendidikan Anak Pada Masa Belajar Dari Rumah

\section{PENDAHULUAN}

Wabah Covid-19 yang luar biasa memaksa presiden RI mengambil kebijakan untuk menentapkan kondisi darurat kesehatan masyarakat. Melalui Keputusan Presiden Republik Indonesia Nomor 11 tahun 2020 ditetapkan Corona Virus Disease 2019 (COVID-19) sebagai jenis penyakit yang menimbulkan Kedaruratan Kesehatan Masyarakat pada tanggal 31 Maret 2020. Sebelumnya, WHO pun telah menyatakan COVID-19 sebagai global pandemik tanggal 11 Maret 2020. Konsekuensi dari dikeluarkannya kebijakan ini adalah dilakukannya serangkaian kebijakan lain antara lain dikeluarkannya Peraturan Menteri Kesehatan No. 9 Tahun 2020 tentang Pedoman Pembatasan Sosial Berskala Besar (PSBB) dalam Rangka Percepatan Penanganan COVID-19.

Pasal 1 Peraturan Pemerintah nomor 21 tahun 2020 tentang PSBB dan Permenkes No. 9 Tahun 2020, PSBB adalah pembatasan kegiatan tertentu penduduk dalam suatu wilayah yang diduga terinfeksi COVID-19 sedemikian rupa untuk mencegah kemungkinan penyebarannya. Pasal 4 Peraturan Pemerintah tersebut menyatakan, "PSBB setidaknya mencakup: peliburan sekolah dan tempat kerja, pembatasan kegiatan keagamaan, dan/atau pembatasan kegiatan di tempat atau fasilitas umum," yang dilakukan dengan tetap mempertimbangkan kebutuhan pendidikan, produktivitas kerja, dan ibadah penduduk.

Sekolah ditutup dan pembelajaran berlangsung dari rumah. Kebijakan social distancing yang dikeluarkan pemerintah dalam rangka mencegah penularan virus tersebut, mengharuskan dilaksanakannya kebijakan Learning from Home (LFH). Aji (Aji 2020) mengemukakan bahwa sekolah ditutup untuk mengurangi kontak secara masif dari orang-orang dan untuk menyelamatkan hidup dari serangan COVID-19. Tentu saja penutupan sekolah tidak boleh menghilangkan hak anak untuk memperoleh pendidikan.

Konsekuensinya, peserta didik yang biasanya belajar di sekolah menjadi menjalankan aktivitasnya dari rumah. Guru pun menjalankan kewajiban mengajarnya secara online, dan karenanya melibatkan orang tua untuk mendampingi anak-anaknya ketika proses belajar. Tanpa persiapan yang matang, tiba-tiba semua orang harus menyesuaikan diri dengan situasi baru yang tercipta karena pandemik COVID19.

Kegiatan belajar dilakukan secara daring (online). Hadirnya "sekolah" di rumah ini menuntut orang tua berperan menjadi pendamping anak dalam belajar, atau bahkan mungkin "pengganti guru." Tentu saja orang tua (ayah dan/atau ibu) memiliki peran penting dalam mendampingi proses belajar anak. Benardes (Benardes 2002) mengemukakan keluarga memiliki empat fungsi yaitu seksual, ekonomi, reproduktif, dan pendidikan. Terkait dengan pemenuhan hak anak dalam memperoleh pendidikan, maka keluarga dalam konteks ini tidak hanya menjalankan perannya sebagai tempat anak memperoleh pendidikan pertamanya (primer), tetapi juga terkait dengan pemenuhan hak anak untuk belajar dalam posisinya sebagai individu warga Negara, yaitu bersekolah. Dalam kondisi normal, hak anak untuk memperoleh pendidikan melalui sekolah ini dilakukan dalam pendampingan guru, tetapi dalam posisi pandemik sebagaimana dijelaskan sebelumnya, anak tidak bisa pergi ke sekolah untuk belajar.

Kegiatan belajar dilakukan secara daring (online). Hadirnya "sekolah" di rumah ini menuntut orang tua berperan menjadi pendamping anak dalam belajar, atau bahkan mungkin "pengganti guru." Tentu saja orang tua (ayah dan/atau ibu) memiliki peran penting dalam mendampingi proses belajar anak. Benardes (Benardes 2002) mengemukakan keluarga memiliki empat fungsi yaitu seksual, ekonomi, reproduktif, dan pendidikan. Terkait dengan pemenuhan hak anak dalam memperoleh pendidikan, maka keluarga dalam konteks ini tidak hanya menjalankan perannya sebagai tempat anak memperoleh 
pendidikan pertamanya (primer), tetapi juga terkait dengan pemenuhan hak anak untuk belajar dalam posisinya sebagai individu warga Negara, yaitu bersekolah. Dalam kondisi normal, hak anak untuk memperoleh pendidikan melalui sekolah ini dilakukan dalam pendampingan guru, tetapi dalam posisi pandemik sebagaimana dijelaskan sebelumnya, anak tidak bisa pergi ke sekolah untuk belajar. Karena itu penelitian ini bermaksud mengungkap bagaimanakah peran orang tua dalam pemenuhan hak pendidikan anak di keluarga pada masa pandemi COVID-19?

Gender memuat seperangkat nilai dan norma yang menjadi ukuran untuk "menjadi" laki-laki dan perempuan. Stereotype merupakan bagian dari kebudayaan yang merupakan nilai, simbol, keyakinan yang terbentuk melalui sistem tertentu (Hurlock 1999). Ada gambaran bagaimana menampilkan diri menjadi laki-laki atau perempuan. Ada karakteristik yang dilekatkan kepadanya secara berbeda; maskulin atau feminine. Konstruksi sosial ini mempengaruhi pikiran dan perilaku setiap individu dalam masyarakat, sehingga ia dijadikan pedoman setiap individu untuk berperilaku (Poloma n.d.).

Dalam ideologi gender patriarkhi, kultur laki-laki mendominasi hampir segala aspek kehidupan, sehingga secara kolektif dan tidak sadar masyarakat melegitimasi dan menerapkan kultur tersebut dalam kehidupannya (Yaqin 2005). Hal ini mempengaruhi pemahaman dan tindakan laki-laki terhadap perempuan dan perempuan dalam melihat dirinya sendiri. Setiap orang membangun persepsi atas dirinya sesuai identitas gender yang disadarinya. Karena itu, budaya patriarkhi ini tidak hanya membatasi kebebasan perempuan, tetapi juga mengorupsi kesadarannya untuk membebaskan dirinya (Beauvoir 1953).

Bagaimana peran tersebut dijalankan oleh orang tua (ayah dan ibu) tergantung pada masing-masing nilai-nilai yang berlaku di masing-masing keluarga. Keluarga yang berada dalam dominasi nilai gender tertentu, maka akan hidup dan berinteraksi sesuai dengan nilai-nilai gender tersebut. Identitas gender pun akan dibentuk sesuai dengan nilai-nilai gender yang berlaku di keluarga dan masyarakat setempat. Menurut Umar (Umar 2010), relasi gender ditentukan oleh pembagian peran dan fungsi di masyarakat, karena dalam gender terdapat harapan-harapan budaya terhadap laki-laki dan perempuan (Lips 2014). Terkait dengan itu, pada umumnya laki-laki sebagai pencari nafkah dan perempuan sebagai ibu rumah tangga (Lips 2017).

Perempuan diidentikkan dengan urusan domestik. Berdasarkan penelitiannya, Damatun, Tantung, dan Memah (Damatun 2017) mengungkapkan bahwa perempuan sebagai pekerja di lingkup hortikultura adalah seorang ibu rumah tangga tidak terlepas dari kewajiban dan tanggung jawabnya yang wajib dilakukan yaitu dalam pekerjaan mengurus rumah tangga. Pembagian peran laki-laki dan perempuan serta pekerjaan rumah menjadi persoalan yang tampaknya sulit berubah (Jatiningsih 2018). Meningkatkan peran serta perempuan dalam kegiatan mencari nafkah bukan berarti mengganggu pekerjaan wanita dalam mengurus rumah tangga (Eliana 2007). Artinya, pekerjaan atau aktivitas produktif perempuan di luar rumah tidak pernah bisa menghapus peran utamanya sebagai seorang ibu dan isteri di lingkup domestic. Karena itu, apapun posisinya, pada umumnya perempuan tetap menjadi penanggung jawab urusan domestic, termasuk di dalamnya pengasuhan dan pendidikan anak-anaknya, bahkan ketika ia pun bekerja di lingkup publik sebagaimana halnya seorang suami. Hegemoni nilainilai gender memengaruhi bagaimana relasi gender itu berlangsung, termasuk dalam kehidupan yang tiba-tiba berubah karena pandemik COVID-19.

Pola relasi antara laki-laki dan perempuan dalam konstruksi gender patriarkhi menyebabkan keduanya mengalami dehumanisasi. 
"Kaum perempuan mengalami dehumanisasi karena ketidakadilan gender dan kaum laki-laki mengalami dehumanisasi karena melanggengkan penindasan gender. ... pola relasi antara keduanya tidak akan pernah saling bersinggungan secara harmonis jika budaya patriarkhis masih bergelindan ikut menjustifikasi pemahaman pola relasi antara keduanya. Dikotomi peran domestik-publik antara lakilaki dan perempuan, menyebabkan perempuan "terpenjara" di ranah domestik dan laki-laki bebas bergerak di ranah publik. Dikotomi tersebut linier dengan pembakuan peran laki-laki sebagai kepala keluarga dan berkewajiban mencari nafkah (publik, produksi), sedangkan perempuan (istri) sebagai ibu rumah tangga yang berkewajiban mengurus pekerjaan domestik" (Fujiati 2014).

Relasi gender di keluarga menggambarkan bagaimana relasi lakilaki dan perempuan dalam berinteraksi di keluarga. Komunikasi yang dilakukan di keluarga bukanlah secara acak, tetapi terpola sehingga tergantung kepada keluarga itu memilih pola yang paling tepat bagi keluarganya, salah satu nilai yang mengatur pola itu adalah nilai gender (Hasan 2017). Terkait ini, manusia baik perempuan maupun laki-laki memiliki perbedaan kodrat sesuai dengan fungsinya masing-masing. Teori struktural fungsional cenderung memandang lakilaki dan perempuan sebagai bagian dari struktur nilai dalam kehidupan masyarakat. Relasi tersebut diyakini menjadi pilihan tepat yang harus dipertahankan karena kontribusinya dalam menciptakan harmoni dalam kehidupan. Konstruksi gender patriarkhi sebagaimana yang telah hidup dan terpelihara dalam kehidupan menyisakan dehumanisasi pada laki-laki dan perempuan, terutama bagi perempuan, yang lebih banyak diposisikan subordinat dan marginal. Hal ini berdampak pada cara orang berpikir, bersikap, dan bertingkahlaku dalam peran yang dilakoninya dalam kehidupan sehari-hari.

\section{METODE}

Penelitian ini menggunakan pendekatan kualitatif eksploratif, yang bermaksud mengungkap fenomena yang ada di balik realita dan hendak ditampilkan secara alami sebagaimana cara mereka menuturkan pokok persoalan yang sedang dikaji. Penelitian ini termasuk jenis penelitian dasar, karena itu penelitian ini memang tidak dimaksudkan untuk menyelesaikan persoalan praktis.

Kegiatan penelitian ini dilaksanakan di Surabaya. Kota yang diasumsikan orang-orang yang tinggal di dalamnya adalah mereka yang relatif melek teknologi, sehingga sebenarnya orang tua pun diasumsikan relatif melek teknologi sehingga pembelajaran yang dilakukan secara online pun sebenarnya tak terlalu menjadi persoalan. Kondisi ini tentu berbeda jika yang diteliti adalah daerah yang orang tua/wali murid adalah mereka yang "jauh" dari kehidupan teknologi. Kegiatan pengumpulan data dilakukan pada bulan September-November 2020.

Subjek dalam penelitian ini adalah orang tua/wali murid dari anak yang tingkat pendidikannya Sekolah Dasar (SD). Subjek penelitian sembilan orang, yang diambil secara purposive berdasarkan kriteria memiliki anak yang sedang bersekolah di tingkat sekolah dasar, dengan mempertimbangkan kecukupan data yang diperoleh.

Fokus dalam penelitian ini adalah: (1) pemahaman orang tua terhadap hak anak dalam belajar, (2) sikap dan tindakan orang tua (ayah dan ibu) dalam memperhatikan, mendampingi, dan memberikan bantuan kepada anaknya dalam proses belajar di rumah selama LFH pada masa pandemik COVID-19. 
Untuk mengungkapnya, dilakukan analisis terhadap pernyataan-pernyataan dan cerita yang disampaikan subjek penelitian tentang hal tersebut.

Data yang telah terkumpul dianalisis secara naratif dengan menggunakan model interaktif Miles dan Hubberman (Miles 1992). Pada dasarnya analisis ini didasarkan pada penyederhanaan dan intepretasi data. Proses ini terdiri atas tiga sub proses analisis, yaitu penyajian data, reduksi data, dan verifikasi, yang merupakan proses yang berkesinambungan dan terkait sampai diperoleh suatu simpulan.

\section{HASIL DAN PEMBAHASAN}

Dalam beberapa hal orang tua harus mengambil beberapa peran yang biasa dilakukan guru di sekolah. Selama ini, orang tua mendampingi anak dalam belajar di rumah dalam waktu dan lingkup yang terbatas, yaitu terutama ketika anaknya mendapatkan pekerjaan rumah atau mengalami kesulitan belajar. Dalam waktu yang tidak terlalu lama dan spesifik tujuannya. Kini dalam masa LFH hal tersebut menjadi kebutuhan yang tidak bisa dihindari. Bahkan banyak yang mengatakan orang tua terpaksa harus menjadi "guru" di sekolah rumahnya.

Orang tua memiliki kesempatan untuk banyak belajar dan mendampingi anaknya dalam belajar. Beberapa peran yang dijalankan orang tua terkait dengan pemenuhan hak belajar anak yang terpaksa berlangsung di rumah adalah mendampingi anak dalam belajar, menyediakan fasilitas belajar anak, dan memotivasi anak dalam belajar.

\section{Mendampingi Anak dalam Belajar}

Pendampingan belajar anak adalah hal yang harus dilakukan orang tua. Anak yang biasanya dalam membiasakan diri belajar didampingi oleh orang tua, dalam waktu cukup panjang harus belajar di rumah. Karena itu menjamin bahwa saatnya belajar anak melakukan aktivitas belajar merupakan hal yang sangat penting dilakukan di setiap keluarga. Waktu belajar anak dimulai pada jam 08.00 di mana pada jam tersebut anak sudah menerima pembelajaran melalui WA Grub yang telah disediakan oleh sekolah.

Apa bentuk pendampingan yang dilakukan ketika anak belajar sangat ditentukan oleh keadaan. Terhadap hal tersebut, Endah mengemukakan, "Setiap hari mendampingi anak belajar 2-3 jam. Menjelaskan seperti guru sebisa mungkin. Mengoreksi tugas anak juga." Ada hal menarik terkait dengan hal terakhir ini yaitu pengakuannya untuk tidak membantu anaknya mengerjakan soal kecuali memahami soal. Endah dengan tegas mengatakan, "Tidak, melainkan memberikan pemahaman soal yang akan dikerjakan." Lebih lanjut Endah mengemukakan bahwa orang tua penting untuk selalu belajar. Hal ini sangat terasa di saat ini ketika harus menjadi guru untuk anaknya. la mengemukakan, "Selama ini, saya banyak menitipkan anak belajar ke sekolah, paling di rumah ya tetap mendampingi sedikit-sedikit, tapi tidak seperti sekarang. Dulu anak sudah diterangkan gurunya, paling di rumah tinggal ngerjakan PR atau tugas membaca. Sekarang orang tua juga harus belajar lagi (sambil tersenyum)." Listya menceritakan bahwa ia mendampingi anaknya untuk belajar sekitar tiga jam per hari di pagi hari, siang dan sore hari. Dikemukakannya, "Kalau dihitung akumulasi mendampingi anak belajar yaitu selama anak saya belajar yaiu sekitar 3-4 jam biasanya pada pagi hari siang dan sore." Lebih lanjut diceritakan tentang aktivitas pendampingan belajar untuk anaknya, "Ya, biasanya kalau lebih pada ke praktek bapaknya yang mendampingi, kalau pada teori maka ke saya, tetapi lebih banyak yang mendominasi saya dari pada bapaknya dalam memantau pembelajaran." Tokoh ayah berperan dalam melakukan pendampingan, terutama ketika kegiatan belajar itu berupa praktik, bukan teori.

Terkait dengan pendampingan anaknya dalam belajar, Erlina mengemukakan bahwa ia tidak selalu mendampingi intens anaknya dalam belajar, tetapi selalu mengontrolnya untuk memastikan bahwa proses belajar 
berjalan dengan baik. Erlina mengemukakan, "Ketika ada yang tidak dimengerti maka saya mengajarinya. Tapi saya selalu memantau proses belajarnya agar semua berjalan lancer. Jika ada kesulitan syaa akan membantunya."

Cara lain dalam mengawal kegiatan anak dalam belajar dari rumah adalah memantau nilai yang diperoleh oleh anak. Ali mengemukakan bahwa ia memantau nilai anaknya, "Ya karena nilai adalah parameter atau tolak ukur keberhasilan proses belajar mengajar, sehingga harus terus dipantau secara berkala." Erlina mengemukakan, "lya, karena nilai harian selalu langsung tampil ketika menyelesaikan tugas." Kontrol terhadap penyelesaian tugas oleh anak menjadi sangat penting dilakukan oleh orang tua. Hal ini sangat dimudahkan pula karena guru menggunakan WA grup dalam berkomunikasi. Ifa mengemukakan, "Ya, pasti karena jika nilai nya jelek maka anak saya tidak bisa. Karena nilai itu salah satu hasil dari proses belajar." Nilai menjadi bukti otentik hasil belajar anaknya. Karena itu, Ifa merasa sangat penting untuk mengawal agar hasil belajar itu baik, tentu saja melalui proses yang baik. Lebih lanjut, Ifa mengemukakan bahwa ia sangat ketat mengawal pengerjaan tugas anaknya. la menuturkan, "Mengoreksi tugas anak dan memastikan tugasnya dikerjakan."

Pendampingan kepada anak, tidak selalu menjadi pekerjaan "setiap saat" bagi orang tuanya. Pada keluarga yang memiliki anak yang sudah mandiri dalam belajar, aktivitas pendampingan itu dilakukan sesuai kebutuhan. Listya mengemukakan,

“.... Biasanya saya lebih mendampingi anak ketika memang dari anak saya yang menemukan kesulitan untuk bertanya pada saya, karena memang anak saya sudah mandiri. ... Ya mengintervensi jika memang ada materi atau soal yang anak saya tidak bisadan itupun sifatnya saya menjelaskan tidak mengerjakan tugasnya."
Senada dengan itu, Ali menceritakan, "Kami mendampingi anak kami dalam belajar daring termasuk mengerjakan tugas. Kami mengarahkan dan membimbing dalam mengerjakan tugas, sedangkan anak kami mengerjakan tugas tersebut sendiri." Meskipun pada umumnya orang tua menyerahkan tanggung jawab penyelesaian tugas itu kepada anaknya, tetapi dalam proses ini, kadang-kadang jika terpaksa, orang tua membantu anaknya menjawab pertanyaan tugas jika anaknya mengalami kesulitan.

\section{Menyediakan fasilitas belajar anak}

Tidak semua matapelajaran dapat ditangani orang tua dengan baik. Memaksimalkan upaya agar dapat menjadi pendamping belajar yang baik bagi anaknya dilakukan oleh orang tua. Ifa mengemukakan, "Menjelaskan seperti guru sebisa mungkin seperti saya akhirnya belajar bisa bahasa Inggris dari youtube agar bisa ngajari anak." Hal lain yang dilakukan ketika mengalami kesulitan dalam pendampingan anak adalah minta tolong kepada orang lain yang dianggap bisa. Ifa menjelaskan, “... iya tapi pada kelas kakaknya saya bingung sehingga saya minta tolong tetangga untuk ngajari, karena saya hanya lulusan SMA dan pelajaran anakanak SD sekarang susahnya minta ampun... Biasanya saya browsing di google, atau tanya kerabat yang jadi guru." Hal yang sama juga dikemukakan oleh Listya.

Saat anak-anak menemui kesulitan, Majid mengemukakan bahwa yang mengatasi semua itu isterinya. Beliau mengaku tidak tahu kesulitan belajar anak, karena isterinya sudah mengatasi persoalan kesulitan belajar anaknya dengan bertanya ke sesama wali murid. Lebih lanjut, Majid mengemukakan, "Saya yang bagian cari uang, sama mengambil raport." Hal yang sama juga dikemukakan oleh Mughni. la mengemukakan bahwa isterinya yang terlibat dalam seluruh proses pendampingan belajar anaknya. la mengatakan, "isteri saya yang tergabung dalam grup orang tua anak saya. Karena 
itu, dia yang mengetahui banyak hal. Saya tidak tahu. Yang mendampingi anak belajar sepenuhnya isteri saya, karena saya bekerja untuk mencari nafkah. Kesulitan belajar anak hampir tidak pernah terjadi, kalau pun ada biasanya anaknya yang langsung bertanya ke gurunya." Hal yang sama juga dikemukakan oleh Hanafi, Mughni, Thamrin.

Ifa mengemukakan bahwa proses belajar daring mengharuskan orang tua memfasilitasi anak dengan perangkat HP. Ifa mengemukakan, "Ya HP saya pinjami pada jam belajar dan membelikan paket internet. HP dipakai gantian karena hanya punya satu." Majid mengemukakan, anakanak menggunakan sarana pembelajaran dengan menggunakan HP. Ya... itu sudah ... sudah memadai kami fasilitasi mereka, berupa buku, jaringan internet, $\mathrm{hp}$, dan lainnya. HP yang digunakan ya HP yang disediakan untuk mereka, gantian. Tapi kadang-kadang jika bersamaan belajarnya, ya pinjam HP ibunya. Listya menceritakan, "Karena LFH nya panjang, akhirnya sy membelikan hp, laptop pengunaanya bergantian, akses internet juga ada di rumah."

Kebutuhan sarana dan prasarana anak berupa HP disadari oleh semua orang tua menjadi kebutuhan belajar bagi anaknya. Karena itu, ada yang sengaja membeli HP meskipun tidak baru hanya untuk memfasilitasi kebutuhan anak dalam belajar. Demikian dikemukakan oleh Hanafi dan Thamrin. "Yang penting anak dapat belajar. Bagaimana lagi... memang kondisinya seperti itu," demikian dikemukakan Thamrin.

Proses pembelajaran yang diberikan guru berupa video ataupun materi bentuk lain yang diakhiri dengan penugasan yang harus disampaikan melalui media foto kepada guru yang bersangkutan. Ifa mengemukakan, "Karena itu HP nya memang harus HP yang bisa dipergunakan untuk video, foto, dan WA, juga internetan."

Menyediakan internet juga menjadi bagian penting untuk menjamin kelancaran proses belajar anak. Endah mengemukakan, "ya.... Sejak WFH yang berkepanjangan, akhirnya kami memutuskan untuk memasang wifi di rumah agar anak lebih mudah dalam belajar." Hal yang sama juga dikemukakan oleh Ali, Hanafi, Ifa, Erlina, dan Thamrin. Selain internet dan HP, hal lain yang dapat dilakukan orang tua terkait sarana dan prasarana belajar ini, Ali menceritakan agar anaknya betah belajar, ia juga menyediakan buku-buku bacaan dan meja belajar yang menarik untuk anaknya.

Peran orang tua dalam memberikan jaminan agar anak dapat belajar dengan baik, membuatnya harus membeli sarana dan prasarana belajar anaknya serta menyediakan jaringan internet. Dengan cara itu, kebutuhan anaknya dalam belajar akan dapat terpenuhi dengan baik. Meskipun tidak ideal, anak akan tetap dapat belajar di masa pandemik ini.

\section{Memotivasi Anak untuk Belajar}

Kebosanan dan kejenuhan menjadi kondisi yang mewarnai kondisi anak selam proses LFH, karena itu sangat penting bagi orang tua memahami kondisi itu. Menuntut anak untuk melakukan berbagai upaya terbaik menjadi hal yang sepertinya kurang dianggap utama. Ifa mengemukakan, "Anak-anak sudah ngerjakan saya sudah senang, krn masih anak kadang males ngerjakan kadang semangat." Ali mengaku bahwa persoalan terbesar bagi anak-anak saat ini adalah motivasi belajarnya. la mengemukakan, "Alhamdulillah materi pelajaran anak bisa kami ikuti dengan baik, namun acapkali kami mengalami kesulitan dalam menjaga motivasi belajar anak agar tetap semangat belajar."

Pelajaran berharga yang diambil informan (orang tua) dalam proses pendampingan anaknya belajar adalah tanggung jawab. Listya mengemukakan bahwa setiap orang tua bertanggungjawab atas pendidikan anaknya. "Karena sudah menjadi tanggungjawab orang tua untuk selalu memantau pada perkembangan yang ada disekolah baik ketika LFH maupun tidak." Sebagaimana dikemukakan Listya, Ifa menceritakan, “ 
Orang tua harus selalu bertanggung jawab terhadap urusan belajar anaknya. Tidak bisa hanya dipasrahkan kepada sekolah atau guru. Ini saya jadi sangat sadar bahwa saya juga harus terus belajar. Belajar sabar dan juga cari ilmu agar bisa ndampingi anak belajar .... Memastikan anak dapat menguasai materi dengan baik ... memfasilitasi ketika anak mengerjakan tugas."

Kebosanan menjadi persoalan tersendiri bagi anak. Selain belajar orang tua juga berperan dalam memelihara semangat belajar anaknya. Hal ini menjadi persoalan tersendiri yang harus dikuatkan oleh orang tua. Berbagai upaya orang tua dilakukan untuk membuat anaknya tetap bersemangat belajar. Salah satu hal dilakukan orang tua adalah membiarkan anaknya bermain di sekitar rumahnya dengan tetap memperhatikan protocol kesehatan.

Kesiapan orang tua dalam mendampingi belajar anak masih menjadi persoalan, karena orang tua belum terbiasa melakukannya. Tanpa persiapan, orang tua harus mengambil alih sebagian tugas guru untuk mendampingi anaknya masing-masing dalam beraktivitas belajar dari rumah selama masa pandemik COVID-19. Dalam proses ini, selain managemen waktu, penguasaan materi dan kerjasama antara kedua orang tua dalam upaya mengoptimalkan pembelajaran anak masih menjadi persoalan.

Kesadaran bahwa anak harus belajar menjadi kekuatan untuk menjamin keberlangsungan anak dalam bersekolah. Di keluarga, orang tua wajib mengasuh, memelihara, mendidik, dan melindungi anak, menumbuhkembangkan anak sesuai dengan kemampuan, bakat, dan minatnya, memberikan pendidikan karakter, dan penanaman nilai budi pekerti pada anak. Peran orang tua dalam pemenuhan hak pendidikan ini anak sangat penting karena dengan cara itu, keluarga akan selalu mengupayakan agar anaknya dapat belajar dengan baik.

Selain sarana dan prasarana, komunikasi keluarga dengan anak juga menjadi prioritas utama untuk mempengaruhi peningkatan kemampuan anak dalam menerima materi pembelajaran dari gurunya. Kemampuan yang dimiliki anak dapat digunakan sebagai tolak ukur oleh orang tua dan dijadikan sebagai latihan evaluasi dalam berkomunikasi dengan guru yang mengajarnya. Hal ini sesuai dengan data yang dianalisis bahwa dengan adanya pandemi COVID-19 ini komunikasi orang tua dengan anak menjadi makin kuat. Orang tua makin mengenal kemampuan anaknya, sehingga orang tua menjadi paham dalam mengukur kemampuan anaknya selama proses pembelajaran. Selain itu kerjasama orang tua menjadi strategi yang saat ini dilakukan untuk upaya bimbingan, pendampingan dan panutan bagi anaknya selama proses pembelajaran. Belajar dari rumah menciptakan ruang belajar baru bagi orang tua. Grup WA dan google menjadi hal yang biasa dibuka dan dimanfaatkan oleh orang tua. Grup WA bahkan menjadi semacam ruang kelas bagi para orang tua, yang ternyata diisi oleh para ibu. Ini kebiasaan baik dan baru yang perlu terus dikembangkan. Belajar sepanjang hayat menjadi efek positif dalam proses LFH ini.

Peran orang tua sebagai pembimbing merupakan peran yang mendasar dalam pengembangan anak. Hal ini karena usia anak sekolah merupakan usia penting dalam pembentukan karakter kepribadian. Di sinilah orang tua berperan sebagai pembimbing. Peran pembimbing jika dikaitkan dengan kebijakan pemerintah untuk melakukan pembelajaran di rumah adalah membimbing anak tentang pembiasaan tentang waktu belajar dan menyelesaikan tugas dari guru. Orang tua dalam hal ini membimbing anak agar dalam mengerjakan tugas dengan bersungguh-sungguh sesuai dengan instruksi dari guru. Peran orang tua sebagai pembimbing dapat disimpulkan bahwa upaya orang tua untuk membiasakan anaknya untuk tepat waktu dan cermat dalam mengerjakan tugas, serta bertanggung jawab dan disiplin.

Peran orang tua sebagai pendamping ialah suatu peran yang 
dilakukan orang tua yang bertujuan untuk mendampingi proses belajar anak di masa pandemi COVID 19. Pendampingan orang tua ini meliputi komunikasi, motivasi, dan curah pendapat. Pendampingan terkait komunikasi adalah upaya yang dilakukan orang tua untuk mentransformasi materi atau informasi dari guru kepada anaknya. Tujuannya adalah agar anak tidak disinformasi atas materi yang diiterima. Pendampingan terkait motivasi merupakan upaya yang dilakukan orang tua untuk menjaga stabilitas atau meningkatnya motivasi belajar anaknya. motivasi belajar anak seringkali naik turun, sehingga perlu adanya pendampingan agar motivasi diri anak tetap terjaga misalnya anak dibanggakan atas ketepatan waktu dalam pengerjaan tugas. Pendampingan terkait curah pendapat merupakan upaya orang tua tentang kemampuan anak dalam menguasai materi yang telah diberikan guru.

Kategori yang terakhir yaitu peran orang tua sebagai motivator dan panutan anak. Peran orang tua ini sangat berpengaruh dalam membangun motivasi belajar anak di masa pandemi COVID-19. Orang tua merupakan seseorang yang memiliki kewajiban dalam pemenuhan biaya administrasi sekolah anaknya dengan cara bekerja dan menghasilkan uang. Akan tetapi di masa pandemi COVID-19 ini orang tua memiliki dua atau lebih kewajiban yakni pemenuhan hak belajar anak. Sesuai dengan kondisi yang terjadi selain bekerja untuk dapat membiayai pendidikan anaknya orang tua harus mendampingi proses belajar anaknya. Kondisi ini yang dapat dijadikan langkah memotivasi belajar pada anaknya bahwa tugas dan kewajiban orang tua dapat ditularkan agar anak dapat belajar dengan semangat.

Pada umumnya masyarakat beranggapan bahwa mengurus anak adalah tugas orangtua perempuan, sedangkan mencari nafkah adalah tugas dari orang tua laki-laki. Sebagaimana temuan Fujiati (Fujiati 2014) mindset dualitas gender ini sering menjadi kendala dalam upaya perkembangan psikologis dan motivasi anak dalam belajar. Gade (Gade n.d.) yang menulis dengan pandangan Islam, makin menguatkan bahwa ibu memiliki peran utama dalam pendidikan anak. Di sisi lain, tanggung jawab dan beban kerja perempuan yang bertambah karena selain domestic kini ada tugas baru untuk melakukan pendampingan belajar terhadap anak yang dipandang sebagai konsekuensi yang harus dipikul oleh ibu agar anakanak memperoleh layanan akan haknya untuk belajar. Tak banyak ayah yang mengambil peran turut terlibat dalam proses pembelajaran anak. Hal ini juga terjadi pada keluarga yang ibunya juga bekerja di ruang publik.

Sebagaimana konstruksi gender patriarkhi yang masih berlaku di masyarakat, ibu memiliki peran dalam melakukan aktivitas-aktivitas domestic. Perawatan dan pendidikan anak merupakan bentuk-bentuk peran ibu yang tidak pernah dapat dialihkan kepada orang lain. Tututan ini semakin menguat ketika anak harus belajar di masa pandemik. lbu yang menjalankan perannya dalam urusan domestic memiliki tambahan tanggung jawab untuk melakukan pendampingan belajar bagi anaknya. Sementara ayah, yang tugas utamanya mencari nafkah tetap dapat konsentrasi mencari nafkah. Anak menjadi prioritas tanggung jawab seorang ibu.

Masyarakat didominasi oleh nilainilai gender patriarkhi, dalam konstruksi ideologi ini laki-laki memiliki peran yang berbeda dengan perempuan. Ada pembagian peran yang kaku berdasarkan jenis kelamin. Perempuan bertanggung jawab atas urusan domestik, perawatan dan pendidikan anak. Oleh karena itu, kebijakan LFH akan berdampak pada aktivitas yang dijalankan anggota keluarga, khususnya orang tua. Sabiq (Sabiq 2020) mengungkapkan bahwa mayoritas orang tua merasa nyaman dengan adanya program pendampingan LFH. Dewi (Dewi 2020) mengungkapkan bahwa pembelajaran daring di SD dapat terlaksana dengan cukup baik apabila 
adanya kerjasama antara guru, siswa dan orang tua dalam belajar di rumah. Pendampingan belajar oleh orang tua ini juga berdampak positif dalam merekatkan hubungan orang tua dengan anak (Cahyati 2020). Namun hal ini tak selalu ditemukan. Secara umum kendalakendala orang tua dalam mendampingi anak belajar di rumah pada masa pandemi COVID-19 adalah kurangnya pemahaman materi oleh orang tua, kesulitan orang tua dalam menumbuhkan minat belajar anak, tidak memiliki cukup waktu untuk mendampingi anak karena harus bekerja, orang tua tidak sabar dalam mendampingi anak saat belajar di rumah, kesulitan orang tua dalam mengoperasikan gadget, dan kendala terkait jangkauan layanan internet (Wardani 2020). Orang tua berkewajiban melakukan pendampingan anak dalam belajar di rumah dan hal ini tidak selalu mudah dilakukan.

Nilai gender patriarkhi mewarnai pembagian peran yang berlangsung dalam kehidupan. Pembagian peran seperti ini tidak pernah dinyatakan secara tertulis dan dinyatakan dalam kesepakatan lisan, namun nilai-nilai ini hidup dan menjiwai semua proses kehidupan. Tidak disadari bahwa kuatnya nilai gender patriarkhi masih terjadi. Kewajiban melakukan penampingan dan pembimbingan belajar lebih menjadi tanggung jawab ibu. Pembagian peran bahwa ibu beraktivitas domestic dan ayah di lingkup publik mendapatkan penguatan dalam kondisi pandemik, saat kebijakan LFH harus dilakukan.

\section{SIMPULAN DAN SARAN}

Semua orang tua menyadari bahwa anak harus tetap belajar di masa pandemik. Pada umumnya mereka sepakat bahwa belajar di sekolah masih mengkhawatirkan kondisinya, sehingga belajar terpaksa dilakukan dari rumah. Tanggung jawab atas pendidikan anaknya ini berdampak pada lahirnya aktivitas orang tua untuk terus belajar antara lain melalaui sarana WA grup kelas yang dibentuk.
Orang tua berperan melakukan pendampingan belajar bagi anaknya, menyediakan sarana dan prasarana belajar, serta memotivasi belajar anak. Dalam proses itu orang tua bertindak melakukan pendampingan, pembimbingan, dan melakukan evaluasi. lbu mengambil peran lebih banyak dalam melakukan pendampingan belajar terhadap anaknya. Karena ayah bekerja mencari nafkah, maka tanpa kesepakatan sudah otomatis terbangun pembagian kerja antara ayah dan ibu dalam mendampingi anak belajar.

Berdasarkan temuan tersebut dapat dikemukakan bahwa pembagian peran dalam keluarga terkait dengan pemenuhan hak anak dalam belajar melalui LFH masih cenderung diwarnai oleh konstruksi gender patriarkhi. Dalam kesadaran para pelakunya, praktik yang terjadi pun semakin meneguhkan masih kuatnya nilai gender patriarkhi di lingkup domestik.

Berdasarkan temuan penelitian, saran yang dapat diajukan adalah: (1) Persepsi diri tentang tugas mencari nafkah dan mengurus rumah tangga bersumber pada sosialisasi nilai gender patriarkhi yang panjang. Nilai-nilai ini perlu didekonstruksi untuk makin menguatkan peran kedua orang tua dalam pembimbingan dan pendampingan anak. (2) Pembagian peran boleh saja terjadi, tetapi hal ini perlu dijaga agar tidak menimbulkan ketidakadilan pada laki-laki atau perempuan dalam berbagai konteks kehidupan. Dekonstruksi nilai-nilai kesetaraan gender dapat diawali dari praktik peran orang tua di rumah.

\section{DAFTAR PUSTAKA}

Aji, R. H. S. (2020). Dampak COVID-19 Pada Pendidikan di Indonesia: Sekolah, Keterampilan, dan Proses Pembelajaranle. SALAM; Jurnal Sosial \& Budaya Syar-I FSH UIN Syarif Hidayatullah Jakarta, 7, 395402.

Beauvoir, S. D. (1953). The Second Sex. London: Jonathan Cape Thirty Badford Square.

Benardes, J. (2002). Family Studies: An 
Introduction. New York: Routledge.

Cahyati, N. \& Kusumah, R. (2020). Peran Orang Tua dalam Menerapkan Pembelajaran di Rumah Saat Pandemi COVID 19. Golden Age, Universitas Hamzanwadi, 4, 152-59.

Damatun, M. (2017). Peran Tenaga Kerja Wanita dalam Usahatani Hortikultura di Kelurahan Wailan, Tomohon Utara, Kota Tomohon. Agri-Sosio Ekonomi Unsrat, 13, 169 - 182.

Dewi, W. A. F. (2020). Dampak COVID19 terhadap Implementasi Pembelajaran Daring di Sekolah Dasar. Ilmu Pendidikan, 2, 55-56.

Eliana, N. \& Ratina, R. (2007). FaktorFaktor Yyang Mempengaruhi Curahan Waktu Kerja Wanita. Ketenagakerjaan, EPP, 4, 11-18.

Fujiati, D. (2014). Relasi Gender dalam Institusi Keluarga dalam Pandangan Teori Sosial dan Feminis. MUWÂZÂH, 6, 32-54.

Gade, F. (2013). 40 Ibu sebagai Madrasah dalam Pendidikan Anak. Jurnal IImiah DIDAKTIKA, 8, 31-40.

Hasan, N. \& Bin, M. Z. (2017). Pola Komunikasi Gender dalam Keluarga. Wardah, 18, 181-200.

Hurlock, E. B. (1999). Psikologi Perkembangan Suatu Pendekatan Sepanjang Rentang Kehidupan (Terjemahan) Live Span Development. Jakarta: Erlangga.

Jatiningsih, O. (2018). The Perspective of Family-Gender Role of PPKn Teacher Candidates at Universitas Negeri Surabaya. Advances in Social Science, Education and Humanities Research, 226, 228-33.

Lips, H. M. (2014). Gender. The Basics. New York: Routledge.

Lips, H. M. (2017). A New Psychology of Women. Gender, Culture, and Ethnicity. Fourth Edition. Illinois: Waveland Press.

Miles, M. B. \& Huberman, A. M. (1992). Qualitative Data Analysis. Terjemahan Oleh: Tjetjep Rohendi Rohidi. Jakarta: UI Press.

Poloma, M. M. (2000). Sosiologi Kontemporer. Jakarta: PT. Raja Grafindo Persada.
Sabiq, A. F. (2020). Persepsi Orang Tua Siswa Tentang Kegiatan Belajar Di Rumah Sebagai Dampak Penyebaran COVID 19. CivicCulture: Jurnal IImu Pendidikan PKn dan Sosial Budaya, 4, 01-07.

Umar, N. (2010). Argumen Kesetaraan Gender: Perspektif Al Qur'an. Jakarta: Paramadina.

Wardani, A. \& Ayriza, Y. (2020). Analisis Kendala Orang Tua dalam Mendampingi Anak Belajar di Rumah pada Masa Pandemi COVID-19. Jurnal Obsesi: Jurnal Pendidikan Anak Usia Dini, 5, 77282.

Yaqin, M. A. (2005). Pendidikan Multikultural: $\quad$ Cross-Cultural Understanding untuk Demokrasi dan Keadilan. Yogyakarta: Pilar Media. 